\title{
Penerapan Model Pembelajaran Inkuiri Terbimbing Pada Materi Impuls dan Momentum di SMA Negeri 11 Samarinda
}

\author{
Maria Imaculata Nano ${ }^{1 *}$, Muliati Syam ${ }^{2}$, dan Zeni Haryanto ${ }^{3}$ \\ 1,2,3 Program Studi Pendidikan Fisika Fakultas Keguruan dan IImu Pendidikan, \\ Universitas Mulawarman, Samarinda-Indonesia \\ *E-mail: imaculatanano97@gmail.com
}

\begin{abstract}
Abstrak
Penelitian ini bertujuan untuk mengetahui kemampuan kognitif siswa setelah diterapkannya model pembelajaran inkuiri terbimbing pada materi impuls dan momentum di SMA Negeri 11 Samarinda. Jenis penelitian yang digunakan adalah penelitian kuantitatif dengan metode quasi eksperimen dan desain penelitian One Group Pretest-Posttest. Sampel yang digunakan sebanyak 35 siswa kelas X MIPA. Teknik pengambilan sampel yang digunakan adalah Purposive Sampling. Instrumen penelitian menggunakan tes tertulis sebanyak 10 soal essay. Hasil rata-rata pretest sebesar 19,86, sedangkan hasil rata-rata posttest sebesar 61,94 . Rata-rata kemampuan kognitif siswa mengalami peningkatan dengan N-Gain sebesar 0,52 dengan kategori sedang. Peningkatan tertinggi pada indikator mengingat diperoleh $\mathrm{N}$-Gain sebesar 0,86 dengan kategori tinggi, sedangkan peningkatan terendah pada indikator mengevaluasi diperoleh $\mathrm{N}$-Gain sebesar 0,29 dengan kategori rendah. Berdasarkan hasi analisis uji-t berpasangan ditemukan bahwa terdapat perbedaan signifikan hasil pretest dengan posttest. Dengan demikian, dapat disimpulkan bahwa terdapat perbedaan kemampuan kognitif yang signifikan antara sebelum dan sesudah diterapkannya model pembelajaran inkuiri terbimbing.
\end{abstract}

Kata kunci: Model Pembelajaran Inkuiri Terbimbing, Kemampuan Kognitif, Momentum Impuls.

\section{Abstract}

This research aims to determine students' cognitive abilities after the implementation of guided inquiry learning models on subject matter impulse and momentum at SMA Negeri 11 Samarinda. Quantitative research was used with a quasi-method of experimentation with One Group Pretest-Posttest research design. The sample was 35 students of Grade X MIPA. The sampling technique used was Purposive Sampling. Written test instruments was used with ten essay questions. The average pre-test result was 19.86, while the average posttest result was 61.94. The average cognitive ability of students improved with $\mathrm{N}$-Gain by 0.52 in the moderate category. The highest increase was in the "remember" indicator with an N-Gain of 0.86 (high category), while the lowest increase in the "evaluating" indicator with an N-Gain of 0.29 (low category). Based on the results of a paired t-test analysis found that there were significant differences between pretest and posttest. Thus, it can be concluded that there are significant differences in cognitive abilities between before and after the implementation of guided inquiry learning models.

Keywords: Guided Inquiry Learning Models, Cognitive Abilities, Impuls Momentum

$\begin{array}{lll}\text { Article History: } & \text { Received: } 10 \text { November } 2020 & \text { Revised: } 5 \text { April } 2021 \\ & \text { Accepted: } 10 \text { Maret } 2021 & \text { Published: } 30 \text { April } 2021\end{array}$

How to cite: Nano, M.I., Syam, M., Haryanto, Z. (2021). Penerapan Model Pembelajaran Inkuiri Terbimbing pada Materi Impuls dan Momentum, di SMA Negeri 11 Samarinda, Jurnal Literasi Pendidikan Fisika, 2(1). pp. 63-72. Retrieved from http://jurnal.fkip.unmul.ac.id/index.php/JLPF

Copyright (c) April 2021, Jurnal Literasi Pendidikan Fisika 
Penerapan Model Pembelajaran...

\section{PENDAHULUAN}

Pendidikan memegang peranan yang sangat penting dalam membangun bangsa, karena berhasilnya pembangunan di dalam bidang pendidikan akan sangat berpengaruh terhadap pembangunan di bidang yang lainnya. Oleh karena itu, pendidikan hendaknya dikelola dengan semaksimal mungkin. Pendidikan adalah salah satu usaha mengembangkan dan meningkatkan sumber daya manusia suatu negara. Proses pendidikan dapat terlaksana melalui kegiatan pembelajaran. Pada lingkup sekolah, pembelajaran adalah proses interaksi antara siswa dan guru serta antara siswa dan siswa untuk menghasilkan suatu perubahan tingkah laku menuju arah lebih baik berdasarkan pengalaman. Guru sebagai garda terdepan dalam mencetak pribadi yang unggul berprestasi dalam mencerdaskan kehidupan bangsa memiliki peranan yang sangat penting dalam hal ini. Berbagai masalahpun muncul dalam dunia pendidikan indonesia, mulai dari sarana dan prasarana yang kurang memadai, kurang profesionalnya tenaga pendidik dan kurikulum yang selalu berubahubah (Sukma, Komariyah \& Syam, 2016). Dalam proses belajar mengajar, dibutuhkan seorang pedidik berkualitas yang mampu mengarahkan anak didik menjadi generasi yang kita harapkan sesuai dengan tujuan dan cita-cita bangsa (Hamiyah \& Mohammad Jauhar, 2014).

Guru adalah seorang pendidik, pembimbing, pelatih, dan pengembang kurikulum yang menciptakan kondisi dan suasana belajar yang kondusif, yaitu suasana belajar yang menyenangkan, menarik, memberi rasa nyaman, memberikan ruang pada siswa untuk berpikir aktif, kreatif, dan inovatif dalam mengeksplorasi dan mengelaborasi kemampuannya. Selain itu tugas guru adalah menyampaikan materi pelajaran kepada siswa dengan menggunakan cara atau metode dalam proses pembelajaran yang dilaksanakan. Keberhasilan guru dalam menyampaikan materi kepada peserta didik sangat tergantung pada metode yang digunakan (Rusman, 2014).

Pendidikan yang mampu mengatasi permasalahan dan mendukung pembangunan dimasa mendatang adalah pendidikan yang mampu mengembangkan potensi peserta didik sehingga mereka mampu menghadapi dan memecahkan permasalahan kehidupan yang dihadapinya (Trianto, 2011). Salah satu upaya yang perlu dilakukan agar potensi peserta didik dapat dikembangkan secara maksimal ialah dengan melaksanakan pendidikan abad 21. Upaya yang dapat dilakukan untuk mencapai tujuan pendidikan abad 21 adalah meningkatkan ranah kognitif peserta didik. Setiap peserta didik memiliki kemampuan kognitif yang berbeda-beda tergantung bagaimana dan sejauh apa kemampuan tersebut dilatihkan. Menurut Anderson dan Kratwohl (2001) dalam Fatiqin (2018), kemampuan kognitif terbagi menjadi enam tingkatan yaitu mengingat (C1), memahami (C2), menerapkan (C3), menganalisis (C4), mengevaluasi (C5) dan menciptakan (C6). Kemampuan kognitif merupakan kegiatan mental yang berkaitan dengan kemampuan seseorang dalam berpikir. Kemampuan kognitif menjadi sangat penting bagi siswa, karena memberikan informasi tentang bagaimana siswa mampu menguasai konsep yang sedang dipelajari. Selain itu, pada kurikulum yang diterapkan di Indonesia, kemampuan kognitif juga menjadi aspek penting yang menjadi sasaran dalam tujuan pembelajaran (Karsilah,2017).

Fisika merupakan salah satu bagian dari ilmu pengetahuan alam (IPA) sehingga pada dasarnya fisika tidak terlepas dari cara berpikir dan cara menyelidiki. Penyelidikan tersebut dapat dimaksudkan untuk mencari tahu tentang kebenaran suatu konsep yang sudah ada atau dapat juga melakukan suatu penemuan konsep yang sudah ada atau dapat juga melakukan perbaikan terhadap konsep yang sudah ada. Mempelari fisika berarti melatih siswa untuk memahami konsep fisika, memecahkan serta menemukan mengapa dan bagaimana peristiwa itu terjadi sehingga siswa lebih mudah memecahkan permasalahan fisika dalam kehidupan sehari-hari.

Berdasarkan hasil pengamatan saat melakukan observasi di SMA Negeri 11 Samarinda dengan guru mata pelajaran fisika kelas X MIPA diketahui bahwa terdapat sebagian besar siswa yang nilai pelajaran fisika masih dibawah KKM. Mata pelajaran fisika masih dianggap sulit oleh peserta didik, sehingga mereka mengalami kesulitan dalam memahami dan menyelesaikan soal pelajaran fisika. 
Penerapan Model Pembelajaran...

Pada proses pembelajaran masih terpusat pada guru sehingga siswa kurang aktif dalam proses pembelajaran,siswa juga sulit untuk memecahkan suatu permasalahan yang diberikan oleh guru. Selain itu saat proses pembelajaran setelah menjelaskan materi guru memberikan contoh soal dan mengevauasi siswa dengan cara memberikan latihan soal, hal ini membuat siswa menjadi kurang aktif dan tidak termotivasi untuk melakukan tanya jawab sehingga hanya sebagian siswa yang memahami materi yang disampaikan. Pembelajaran fisika yang monoton mengakibatkan pembelajaran fisika terasa sulit dan kurang menarik, hal ini dapat berdampak pada rendahnya kemampuan kognitif siswa. Berdasarkan masalah tersebut, peneliti dapat mengetahui bahwa kemampuan kognitif siswa di sekolah masih rendah.

Salah satu upaya memecahkan masalah tersebut yaitu model pembelajaran yang mampu meningkatkan kemampuan kognitif siswa. Kemampuan kognitif siswa dapat ditingkatkan melalui proses pembelajaran. Salah satu cara yang digunakan adalah memilih model pembelajaran yang tepat. Salah satu model pembelajaran yang memberikan kesempatan bagi siswa untuk menemukan sendiri pengetahuannya, berpikir aktif dalam pembelajaran dan mengembangkan kemampuan berpikir siswa adalah model pembelajaran inkuiri terbimbing (Fatiqin, 2018).

Model pembelajaran inkuri terbimbing adalah salah satu cara dalam pembelajaran yang dugunakan dalam pendidikan sains. Pembelajaran inkuiri terbimbing diawali dari permasalahan yang diajukan guru, kemudian siswa melakukan pengamatan sampai pada kegiatan menyimpulkan (Trianto, 2011). Model pembelajaran inkuiri terbimbing merupakan model pembelajaran yang menekankan dalam proses penemuan konsep dan hubungan antar konsep dimana siswa merancang sendiri percobaan sehingga peran siswa lebih dominan, sedangkan guru membimbing siswa ke arah yang tepat/benar. Inkuiri terbimbing berorientasi pada aktivitas kelas yang berpusat pada siswa dan memungkinkan siswa belajar memanfaatkan berbagai sumber belajar yang tidak hanya menjadikan guru sebagai sumber belajar. Siswa secara aktif akan terlibat dalam proses mentalnya melalui kegiatan pengamatan, pengukuran, dan pengumpulan data untuk menarik suatu kesimpulan. Dengan menerapkan pembelajaran berbasis inkuiri akan memicu keingintahuan siswa dalam menemukan hal-hal yang ingin diketahui siswa (Nurdyansyah, 2016). la menyatakan bahwa pada model pembelajaran inkuiri terbimbing ada beberapa tahapan yaitu identifikasi masalah dan melakukan pengamatan, mengajukan pertanyaan, merencanakan penyelidikan, mengumpulkan data, menganalisis data, membuat kesimpulan, dan mengkomunikasikan hasil. Pembelajaran inkuiri terbimbing diterapkan agar siswa bebas mengembangkan konsep yang mereka pelajari. Siswa diberi kesempatan untuk memecahkan masalah yang mereka hadapi secara individu atau berkelompok, di dalam kelas siswa dilatih untuk berinteraksi dengan kawan sebayanya untuk saling bertukar informasi (Sumarni, 2017). Dalam model pembelajaran inkuiri terbimbing guru sebagai fasilitator yang membimbing dan mengarahkan siswa untuk menemukan konsep sendiri, sehingga siswa lebih aktif dalam pembelajaran dan kemampuan kognitif siswa dapat ditingkatkan. Kelebihan model pembelajaran inkuiri terbimbing adalah siswa dapat mengembangkan keterampilan bahasa, membaca dan keterampilan sosial, siswa dapat membangun pemahaman sendiri, siswa mendapat kebebasan dalam melakukan penelitian, siswa dapat meningkatkan motivasi belajar dan mengembangkan straregi belajar untuk menyelesaikan masalah (Nurdyansyah, 2016).

\section{METODE}

Jenis penelitian yang digunakan adalah penelitian kuantitatif. Metode yang digunakan dalam penelitian ini adalah metode eksperimen semu (Quasy experiment). Desain penelitian yang digunakan adalah One-Group Pretest-Posttest Design. Pada desain ini terdapat pretest, sebelum diberi perlakuan. Dengan demikian hasil perlakuan dapat diketahui lebih akurat, karena dapat membandingkan dengan keadaan sebelum diberi perlakuan. Setelah diberi perlakuan selama 3 kali pertemuan, sampel diberi 
Penerapan Model Pembelajaran...

posttest dengan instrumen soal yang mengacu pada indikator kemampuan kognitif.

Penelitian ini dilaksanakan pada bulan Februari-Maret 2020 semester genap tahun ajaran 2019/2020 di SMA Negeri 11 Samarinda yang terletak di JI. Pelita IV Sambutan Kec. Sambutan, kota Samarinda. Populasi pada penelitian ini adalah siswa kelas X MIPA 2. Sampel yang digunakan pada penelitian ini terdiri dari satu kelas sebanyak 35 siswa. Teknik pengambilan sampel yaitu purposive sampling, dengan pertimbangan tertentu dipilihnya kelas X MIPA 2 sebagai sampel karena kelas ini memiliki rata-rata kemampuan kognitif yang sama. Teknik pengambilan data pada penelitian ini yaitu teknik tes, yang terdiri dari pretest dan posttest. Soal pretest diberikan untuk mengetahui kemampuan awal siswa sebelum diterapkannya model pembelajaran inkuiri terbimbing. Soal posttest diberikan kepada siswa pada akhir proses pembelajaran setelah diterapkannya model pembelajaran inkuiri terbimbing. Soal pretest dan posttest berupa soal essay (uraian) sebanyak 10 soal yang mengacu pada indikator kemampuan kognitif yaitu mengingat (C1), memahami (C2), mengaplikasikan (C3), menganalisis (C4), mengevaluasi (C5), mencipta (C6).

Teknik analisis data yang digunakan pada penlitian ini yaitu nilai rata-rata (mean) untuk mengetahui rata-rata nilai hasil belajar kognitif. Persentase hasil belajar untuk mengetahui persentase hasil belajar kognitif siswa. Analisis N-Gain untuk mengetahui peningkatan kemampuan kognitif. Kemudian dilakukan uji hipotesis (uji t berpasangan) untuk mengetahui perbedaan kemampuan kognitif antara sebelum dan sesudah diterapkan model pembelajaran inkuiri terbimbing. Sebelum dilakukan uji $t$ berpasangan terlebih dahulu dilakukan uji normalitas untuk mengetahui apakah data tersebut berdistribusi normal atau tidak menggunakan SPSS 20 for windows.

\section{HASIL DAN PEMBAHASAN}

HASIL

Rata-rata pretest peserta didik sebelum diterapkan model pembelajaran inkuiri terbimbing yaitu sebesar 19,86 dengan 20 siswa memperoleh kategori rendah dan 15 siswa memperoleh kategori sangat rendah. Agar lebih jelas, data tingkat keberhasilan pretest siswa dapat dilihat pada Tabel 1 berikut:

Tabel 1. Tingkat Keberhasilan Pretest Siswa

\begin{tabular}{ccccc}
\hline No & Tingkat Keberhasilan & Kriteria & Frekuensi & Persentase \\
\hline 1 & $81 \%-100 \%$ & Sangat Tinggi & 0 & $0 \%$ \\
\hline 2 & $61 \%-80 \%$ & Tinggi & 0 & $0 \%$ \\
\hline 3 & $41 \%-60 \%$ & Cukup & 0 & $0 \%$ \\
\hline 4 & $21 \%-40 \%$ & Rendah & 21 & $57 \%$ \\
\hline 5 & $0 \%-21 \%$ & Sangat Rendah & 15 & $43 \%$ \\
\hline
\end{tabular}

Rata-rata siswa setelah diterapkan model pembelajaran inkuiri terbimbing yaitu sebesar 61,94 . Hal ini menunjukkan bahwa setelah diterapkan model pembelajaran inkuiri terbimbing terdapat peningkatan kemampuan kognitif siswa dari sebelum diberi perlakuan. Data tingkat keberhasilan posttest siswa dapat dilihat pada Tabel 2 berikut :

Tabel 2. Tingkat Keberhasilan Posttest Siswa

\begin{tabular}{ccccc}
\hline No & Tingkat Keberhasilan & Kriteria & Frekuensi & Persentase \\
\hline 1 & $81 \%-100 \%$ & Sangat Tinggi & 6 & $17 \%$ \\
\hline 2 & $61 \%-80 \%$ & Tinggi & 16 & $46 \%$ \\
\hline 3 & $41 \%-60 \%$ & Cukup & 11 & $31 \%$ \\
\hline 4 & $21 \%-40 \%$ & Rendah & 2 & $6 \%$ \\
\hline 5 & $0 \%-21 \%$ & Sangat Rendah & 0 & $0 \%$ \\
\hline
\end{tabular}


Penerapan Model Pembelajaran...

Peningkatan hasil pretest dan posttest dapat diidentifikasi dengan mencari N-Gain nilai rata-rata siswa pada pokok bahasan materi momentum dan impuls. N-Gain memberikan gambaran peningkatan nilai kemampuan kognitif siswa antara pretest dan posttest dapat dilihat pada Tabel 3 sebagai berikut

Tabel 3. Nilai N-Gain Rata-Rata Siswa Kelas X MIPA 2

\begin{tabular}{cccccc}
\hline Pre-test & Kriteria & Post-test & Kriteria & N-Gain & Kriteria \\
\hline 19,86 & Sangat Rendah & 61,94 & Tinggi & 0,53 & Sedang \\
\hline
\end{tabular}

Berdasarkan data tersebut, diketahui terdapat peningkatan kemampuan kognitif siswa dengan NGain sebesar 0,53 kriteria sedang. Terdapat 6 indikator kemampuan kognitif siswa yang digunakan dalam penelitian ini. Perolehan peningkatan kemampuan kognitif siswa setiap indikator dapat dilihat pada Tabel 4 sebagai berikut:

Tabel 4. Analisis N-Gain pada Setiap Indikator Kemampuan Kognitif

\begin{tabular}{cccccc}
\hline \multirow{2}{*}{ Indikator } & \multicolumn{2}{c}{ Rata-Rata } & $\begin{array}{c}\text { Skor } \\
\text { maksimum }\end{array}$ & N-Gain & Kriteria \\
& Pre-test & Post-test & & & \\
\hline Mengingat (C1) & 1,63 & 4,54 & 5 & 0,86 & Tinggi \\
\hline Memahami (C2) & 2,26 & 4,43 & 5 & 0,76 & Tinggi \\
\hline Mengaplikasikan (C3) & 10,31 & 33,49 & 50 & 0,58 & Sedang \\
\hline Menganalisis (C4) & 2,00 & 7,11 & 15 & 0,39 & Sedang \\
\hline Mengevaluasi (C5) & 3,26 & 5,20 & 10 & 0,29 & Rendah \\
\hline Mencipta (C6) & 0,03 & 7,23 & 15 & 0,48 & Sedang \\
\hline
\end{tabular}

Berdasarkan tabel menunjukkan bahwa peningkatan tertinggi pada indikator mengingat (C1) dengan perolehan $\mathrm{N}$-Gain sebesar 0,86 dengan kategori tinggi, sedangkan peningkatan terendah pada indikator mengevaluasi (C5) dengan perolehan N-Gain sebesar 0,29 dengan kategori rendah. Bila digambarkan dalam bentuk grafik perolehan kenaikan dari tiap indikator kemampuan kognitif siswa yaitu sebagai berikut:

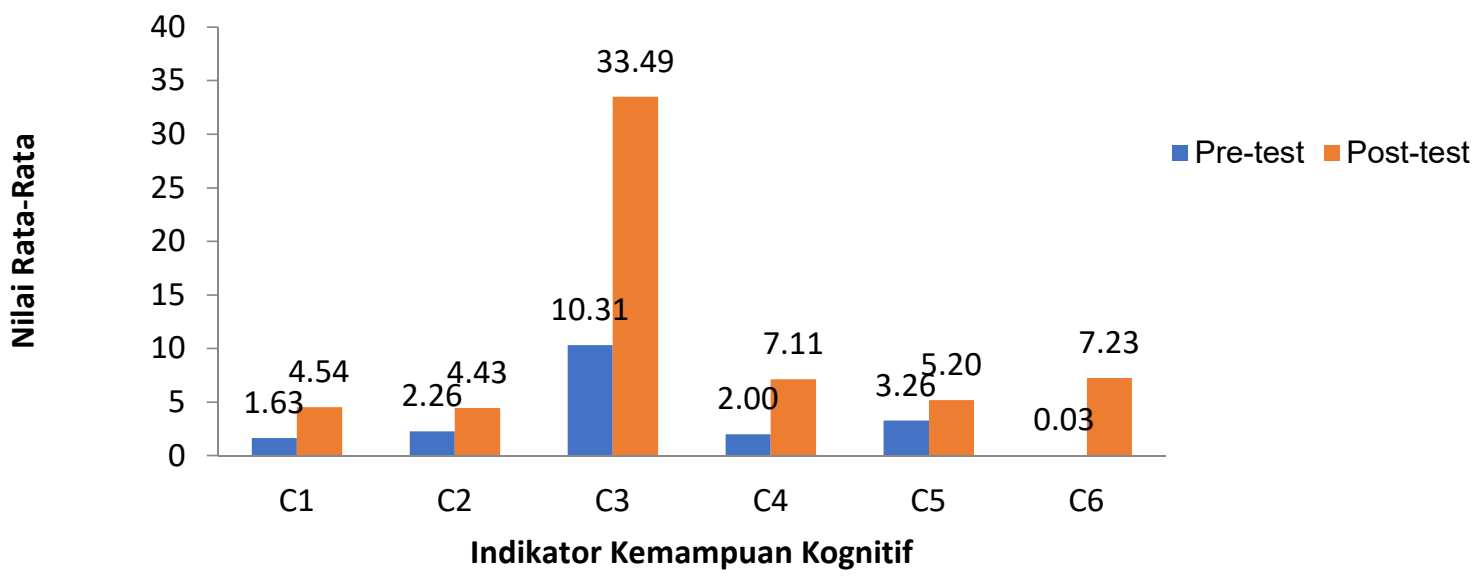

Gambar 1. Grafik Peningkatan Rata-Rata Skor Tiap Indikator Pretest ke Posttest Kemampuan Kognitif Siswa Untuk melihat persentase dari N-Gain rata-rata siswa kelas X MIPA 2 SMA Negeri 11 Samarinda dapat dilihat pada Tabel 5 sebagai berikut :

Tabel 5. Persentase Nilai N-Gain Rata-Rata Siswa

\begin{tabular}{cccc}
\hline Nilai & Kriteria & Jumlah Siswa & Persentase \\
\hline $\mathrm{g} \geq 0,7$ & Tinggi & 9 & $26 \%$ \\
\hline $0,3 \leq \mathrm{g} \leq 0,7$ & Sedang & 20 & $57 \%$ \\
\hline $\mathrm{g}<0,3$ & Rendah & 6 & $17 \%$ \\
\hline
\end{tabular}


Penerapan Model Pembelajaran...

Hasil uji normalitas data pretest dan posttest menggunakan metode Shapiro Wilk dengan bantuan software SPSS 20 for windows dapat dilihat pada Tabel 6.

Tabel 6. Hasil Uji Normalitas Data Pretest dan Posttest Tests of Normality

\begin{tabular}{lccccr}
\hline & \multicolumn{3}{c}{ Shapiro-Wilk } \\
\cline { 2 - 6 } & Statistic & df & \multicolumn{2}{c}{ Sig. } \\
\hline PRE-TEST & & .975 & & 35 & .596 \\
\hline POST-TEST & & .966 & & 35 & .335 \\
\hline
\end{tabular}

*. This is a lower bound of the true significance.

a. Lilliefors Significance Correction

Hasil uji normaliltas pada pretest dan posttest tersebut menunjukkan nilai $p$-value masing-masing sebesar 0,596 dan 0,335 , sehingga dapat disimpulkan bahwa data peningkatan kemampuan kognitif siswa terdistribusi normal karena nilai singnifikansinya lebih besar dari 0,05.

Setelah diketahui bahwa data terdistribusi normal, dilakukan uji hipotesis menggunakan uji-t berpasangan dengan bantuan Software SPSS 20 for Windows. Uji hipotesis dilakukan untuk mengetahui ada tidaknya perbedaan kemampuan kognitif siswa antara sebelum dan setelah diterapkannya model pembelajaran inkuiri terbimbing. Hasil uji hipotesis dapat dilihat pada Tabel 7 sebagai berikut :

Tabel 7. Hasil Analisis Uji-t Berpasangan

\begin{tabular}{|c|c|c|c|c|}
\hline & & $\mathbf{t}$ & df & $\begin{array}{l}\text { Sig. (2- } \\
\text { tailed) }\end{array}$ \\
\hline Pair 1 & $\begin{array}{l}\text { PRE-TEST - } \\
\text { POST-TEST }\end{array}$ & -15.190 & 34 & .000 \\
\hline
\end{tabular}

Berdasarkan hasil uji hipotesis dengan uji-t berpasangan didapatkan bahwa nilai signifikasinya yang lebih kecil dari taraf signifikasi 0.05 dan nilai t hitung 15.190, sehingga dengan taraf signifikasi kurang dari 0.05 maka dapat disimpulkan $\mathrm{H}_{0}$ ditolak dan $\mathrm{H}_{a}$ diterima yaitu terdapat perbedaan yang signifikan hasil pre-test dan post-test yang artinya bahwa ada perbedaan kemampuan kognitif siswa yang signifikan antara sebelum dan sesudah diterapkan model pembelajaran inkuiri terbimbing.

\section{PEMBAHASAN}

Penelitian ini betujuan untuk mengetahui kemampuan kognitif siswa setelah diterapkannya model pembelajaran inkuiri terbimbing pada materi momentum dan impuls di SMA Negeri 11 Samarinda tahun ajaran 2019/2020. Sebelum melaksanakan pembelajaran dengan menggunakan model pembelajaran inkuiri terbimbing terlebih dahulu diberikan pre-test pada pertemuan pertama. Adanya pre-test ini untuk mengetahui kemampuan kognitif awal siswa terhadap materi momentum dan impuls dengan mengerjakan tes berbentuk essay sebanyak 10 butir soal. Dari hasil jawaban tersebut, didapatkan data awal kemampuan berpikir kognitif siswa. Setelah dilakukan pretest tersebut, selanjutnya siswa diberikan perlakuan pembelajaran dengan model ikuiri terbimbing pada pertemuan selanjutnya. Kegiatan penelitian yang dilakukan selama proses pembelajaran dimulai dengan menyampaikan tujuan pembelajaran, kemudian menggunakan model pembelajaran inkuiri terbimbing. Dimulai dari tahap menyajikan pertanyaan atau masalah, siswa mengamati gambar atau video yang berkaitan dengan materi momentum dan impuls, setelah itu tahap membuat hipotesis guru membimbing siswa untuk

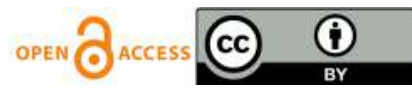


Penerapan Model Pembelajaran...

membuat hipotesis yang relevan, kemudian tahap merancang percobaan, guru meminta siswa untuk merancang percobaan sesuai dengan langkah-langkah percobaan yang ada, kemudian memasuki tahap melakukan percobaan untuk memperoleh data, guru membimbing siswa mendapatkan data melalui percobaan, kemudian tahap mengumpulkan dan menganalisis data guru meminta siswa untuk berdiskusi dengan kelompok masing-masing untuk menganalisis data yang diperoleh untuk menyelesaikan masalah, kemudian yang terakhir tahap menyimpulkan guru membimbing siswa untuk membuat kesimpulan berdasarkan data yang diperoleh dan setiap perwakilan kelompok mempresentasikan hasilnya di depan kelas. Setelah melakukan semua tahap pada model pembelajaran dilakukan kegiatan post-test agar dapat mengetahui kemampuan kognitif masing-masing siswa pada akhir pertemuan. Kegiatan ini berfungsi sebagai dasar bahwa siswa tersebut telah memahami materi hingga akhir pembelajaran. Soal post-test sesuai dengan indikator kemampuan kognitif yaitu C1,C2,C3,C4,C5 dan C6.

Berdasarkan hasil analisis data, ditunjukkan bahwa model pembelajaran inkuiri terbimbing dapat meningkatkan kemampuan kognitif siswa. Hal ini terlihat dari perhitungan, sebelum diterapkan model pembelajaran inkuiri terbimbing diperoleh nilai rata-rata pretest yaitu 19,86 dengan 20 siswa memperoleh kriteria rendah dan 15 siswa memperoleh kriteria sangat rendah. Sedangkan setelah diterapkan model pembelajaran inkuiri terbimbing diperoleh nilai rata-rata posttest yaitu sebesar 61,94 dengan 6 siswa memperoleh kriteria sangat tinggi, 16 siswa memperoleh kriteria tinggi, 11 siswa memperoleh kriteria cukup dan 2 siswa memperoleh kriteria rendah. Rendahnya kemampuan kognitif awal siswa sebelum diberikan pembelajaran dengan model pembelajaran inkuiri terbimbing karena siswa terbiasa dengan model pembelajaran konvensional. Namun setelah diberikan pembelajaran dengan model pembelajaran inkuiri terbimbing maka terdapat peningkatan kemampuan kognitif siswa.

Peningkatan kemampuan kognitif dianalisis menggunakan N-Gain. Berdasarkan tabel 3 diperoleh nilai $\mathrm{N}-$ Gain sebesar 0,53 dengan kriteria sedang. Hal ini menunjukkan bahwa dengan menerapkan model pembelajaran inkuiri dapat meningkatkan kemampuan kognitif siswa, semakin sering menerapkan model pembelajaran inkuiri terbimbing maka akan semakin meningkat kemauan rasa belajar siswa sehingga rasa ingin tahu siswa akan lebih meningkat pada materi yang diajarkan dan tidak dipungkiri kemampuan kognitif siswa juga akan mengalami peningkatan. Hasil penelitian ini sejalan dengan penelitian yang dilakukan oleh Fatiqin (2018) yang menunjukkan model pembelajaran inkuiri terbimbing dapat meningkatkan kemampuan kognitif siswa.

Instrumen yang digunakan untuk mengukur kemampuan kognitif siswa merupakan tes tertulis berupa essay sebanyak 10 butir soal berdasarkan indikator kemampuan kognitif Taksonomi Bloom revisi yaitu Mengingat (C1), Memahami (C2), Mengaplikasikan (C3), Menganalisis (C4), Mengevaluasi (C5), Mencipta (C6).

$\mathrm{N}$-Gain setiap indikator, menunjukkan hasil yang bervariasi. Berdasarkan tabel 4 analisis $\mathrm{N}$-Gain pada setiap indikator kemampuan kognitif dijelaskan perolehan N-Gain setiap indikator yaitu pada indikator mengingat (C1) diperoleh nilai rata-rata pre-test sebesar 1,63 dan post-test sebesar 4,54 dengan nilai $\mathrm{N}-$ Gain sebesar 0,86 yang termasuk dalam kategori tinggi. Hasil ini sejalan dengan penelitian yang dilakukan oleh Wahyuni (2018) dan Yulianci (2017), keduanya sama-sama menunjukkan peningkatan indikator mengingat adalah tinggi. Hal ini menandakan bahwa melalui model pembelajaran inkuiri terbimbing siswa dilatih untuk lebih mudah menyatakan kembali fakta, konsep yang telah dipelajari. Pernyataan yang dikemukakan oleh Sumarni (2017) juga sangat mendukung hasil dari penelitian ini. Menurut Sumarni (2017) keaktifan peserta didik dapat dilihat dari aktifnya peserta didik saat mengerjakan tugas kelompok serta tugas individu yang diberikan dengan menemukan sendiri jawaban dari permasalahan sehingga peserta didik dapat lebih lama mengingat informasi pengetahuan yang ditemukannya.

Pada indikator memahami (C2) diperoleh nilai rata-rata pretest sebesar 2,26 dan nilai rata-rata posttest sebesar 4,43 dengan nilai $\mathrm{N}-$ Gain sebesar 0,76 yang termasuk kategori tinggi. Hasil ini sejalan dengan penelitian yang dilakukan oleh Wahyuni (2018) dan Yulianci (2017), keduanya sama-sama

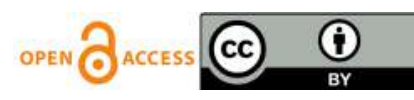


Penerapan Model Pembelajaran...

menunjukkan peningkatan indikator memahami (C2) termasuk dalam kategori tinggi. Hal ini menunjukkan bahwa melalui model pembelajaran inkuiri terbimbing cara berfikir siswa dilatih untuk lebih mudah menjelaskan dan memberi contoh sesuai konsep momentum dan impuls. Menurut Trianto (2011) model pembelajaran inkuiri memberikan kesempatan kepada siswa untuk menemukan sendiri pengetahuannya, berpikir aktif dalam pembelajaran dan mengembangkan kemampuan berpikir peserta didik.

Pada indikator mengaplikasikan (C3) diperoleh nilai rata-rata pretest sebesar 10,31 dan nilai ratarata post-test sebesar 33,49 dengan nilai $\mathrm{N}-\mathrm{G}$ ain sebesar 0,58 atau peningkatannya sebesar $58 \%$ yang termasuk dalam kategori sedang. Hasil penelitian yang dilakukan oleh Fatiqin (2018) juga mengalami peningkatan pada indikator mengaplikasikan (C3), hal ini menunjukkan bahwa dengan menerapkan model pembelajaran inkuiri siswa sudah bisa menerapkan pengetahuan yang dimiliki dan menggunakan prinsip, teori yang dipelajari dalam memecahkan soal yang yang diberikan. Penelitian Wahyuni (2018) juga menunjukkan bahwa setelah diberi perlakuan nilai rata-rata pada aspek C3 mengalami peningkatan. Hal ini karena dengan bantuan guru melatih dirinya untuk menggunakan konsep-konsep yang telah dipelajari melalui kegiatan eksperimen untuk menjawab soal hitungan.

Indikator menganalisis (C4) diperoleh nilai rata-rata pretest sebesar 2,00 dan nilai rata-rata posttest sebesar 7,11 dengan nilai $\mathrm{N}$-Gain sebesar 0,39 atau peningkatannya sebesar $39 \%$ yang termasuk dalam kategori sedang. Hasil ini sejalan dengan penelitian yang dilakukan oleh Wahyuni (2018) dengan peningkatan sebesar $38,5 \%$ yang termasuk dalam kategori sedang. Hal ini menunjukkan bahwa melalui model pembelajaran inkuiri terbimbing, siswa bisa menganalisis atau merinci pengetahuan dan memahami hubungan diantara bagian satu dengan bagian lain dalam memecahkan soal. Pernyataan yang dikemukakan oleh Amijaya (2018) juga sangat mendukung hasil dari penelitian ini. Menurut Amijaya (2018) dengan diterapkannya model pembelajaran inkuiri terbimbing siswa dituntut untuk menganalisis data-data yang mendukung, menguji hipotesis dan membuat kesimpulan, sehingga kemampuan menganalisis siswa akan meningkat.

Indikator mengevaluasi (C5) diperoleh nilai rata-rata pre-test sebesar 3,26 dan nilai rata-rata posttest sebesar 5,20 dengan nilai $\mathrm{N}-$ Gain sebesar 0,29 atau peningkatannya sebesar $29 \%$ yang termasuk dalam kategori rendah. Penelitian Suranti (2016) menunjukkan bahwa diperoleh nilai yang rendah pada soal dengan aspek kognitif tinggi karena tingkat kesukaran soal semakin tinggi untuk ranah kognitif yang lebih tinggi. Hal ini menunjukkan sebagian siswa belum bisa memberikan keputusan terhadap permasalahan yang diberikan, sehingga pada indikator C5 peningkatannya termasuk dalam kategori rendah.

Indikator mencipta (C6) diperoleh nilai rata-rata pre-test sebesar 0,03 dan nilai rata-rata post-test sebesar 7,23 dengan nilai $\mathrm{N}$-Gain sebesar 0,48 atau peningkatannya sebesar $48 \%$ yang termasuk dalam kategori sedang. Hasil ini sejalan dengan penelitian yang dilakukan oleh Yulianci (2017) yang menunjukkan peningkatan indikator mencipta (C6) berada dalam kategori sedang dengan peningkatannya sebesar $57,14 \%$. Hal ini menunjukkan melalui model pembelajaran inkuiri terbimbing siswa sudah bisa membuktikan sesuatu kejadian menggunakan rumus.

Sesuai dengan perhitungan pada tabel 5 yang menunjukkan kenaikan N-Gain terhadap kemampuan kognitif siswa berdasarkan nilai pre-test dan post-test. Pada rata-rata persentase nilai $\mathrm{N}$-Gain terdapat $26 \%$ dengan jumlah 9 siswa yang termasuk dalam kategori tinggi, 57\% dengan jumlah 20 siswa yang termasuk kategori sedang dan $17 \%$ dengan jumlah 6 siswa yang termasuk kategori rendah. Hasil tersebut menunjukkan bahwa model pembelajaran inkuiri terbimbing dapat meningkatkan kemampuan kognitif siswa, karena model pembelajaran ini menekankan pada aktivitas siswa secara maksimal untuk mencari dan menemukan. Jadi, pada model ini siswa beperan lebih aktif dan tidak hanya mendengarkan tetapi terlibat langsung dalam hal menemukan dan memecahkan permasalahan yang diberikan.

Selanjutnya data dianalisis menggunakan uji normalitas untuk mengetahui apakah data terdistribusi normal atau tidak yang dapat dilihat pada tabel 6. hasil uji mormalitas pada pre-test dan post-test

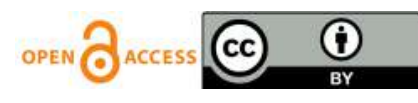


Penerapan Model Pembelajaran...

tersebut menunjukkan nilai $p$-value masing-masing sebesar 0,596 dan 0,335 , sehingga dapat disimpulkan data peningkatan kemampuan kognitif siswa terdistribusi dengan normal karena lebih dari 0,05 .

Langkah berikutnya dilakukan pengujian hipotesis dengan uji-t berpasangan untuk mengetahui ada tidaknya perbedaan kemampuan kognitif siswa antara sebelum dan setelah diterapkannya model pembelajaran inkuiri terbimbing pada siswa kelas X MIPA 2 SMA Negeri 11 Samarinda. Tabel 7 menunjukkan hasil analisis data dengan model pembelajaran inkuiri terbimbing ternyata menghasilkan perbedaan rata-rata nilai pre-test dan post-test yang signifikan yaitu 0.000 . Perhitungan nilai rata-rata pre-test dan post-test menunjukkan t-hitung sebesar 15.190. Hal ini menunjukan bahwa $\mathrm{H}_{a}$ diterima dan $\mathrm{H}_{0}$ ditolak. Berdasarkan analisis tersebut dapat disimpulkan bahwa ada perbedaan kemampuan kognitif yang signifikan antara sebelum dan sesudah diterapkannya model pembelajaran inkuiri terbimbing. Terlihat bahwa model pembelajaran inkuiri terbimbing yang didapatkan siswa selama melakukan pembelajaran dengan mengerjakan lembar kerja dan pengamatan langsung dapat meningkatkan kemampuan kognitif siswa kelas X MIPA 2 SMA Negeri 11 Samarinda pada materi momentum dan impuls, hal ini disebabkan melalui model inkuiri terbimbing siswa dilatih menggunakan segala potensinya terutama proses mentalnya untuk menemukan sendiri konsep-konsep atau prinsipprinsip pembelajaran fisika sehingga keaktifan siswa dalam pembelajaran fisika untuk mengembangkan kemampuan kognitif siswa meningkat. Berdasarkan penelitian yang dilakukan dapat disimpulkan bahwa meskipun peningkatannya termasuk kategori sedang, namun penerapan model pembelajaran inkuiri terbimbing dapat meningkatkan kemampuan kognitif siswa kelas X MIPA 2 SMA Negeri 11 Samarinda pada materi Momentum dan Impuls. Hal ini relevan dengan penelitian Fatiqin (2018) dimana hasil penelitiannya menunjukkan bahwa model pembelajaran inkuiri terbimbing dapat meningkatkan kemampuan kognitif siswa. Selain itu, penelitian ini relevan dengan penelitian yang dilakukan oleh beberapa dosen dan guru fisika, antara lain yaitu Sinuraya (2019), Putri (2009), dan Sihombing (2015), sebagian besar memberikan hasil penelitian bahwa model pembelajaran inkuiri terbimbing dapat meningkatkan hasil belajar ranah kognitif.

\section{PENUTUP}

Berdasarkan hasil analisis data penelitian yang dilakukan di kelas X MIPA 2 SMA Negeri 11 Samarinda dapat disimpukan bahwa, terdapat peningkatan kemampuan kognitif siswa antara sebelum dan sesudah diterapkan model pembelajaran inkuiri terbimbing pada materi momentum dan impuls. $\mathrm{Hal}$ ini didasarkan pada hasil perhitungan uji $\mathrm{N}$-Gain dengan hasil peningkatan sebesar 0,59 yang termasuk dalam kategori sedang.

Adapun saran yang dapat penulis berikan adalah sebagai berikut : (1) Bagi peserta didik agar terus belajar dan berlatih serta meningkatkan belajarnya, sehingga mempunyai kemampuan kognitif yang tinggi dan baik dalam mengatasi permasalahan dalam pembelajaran. (2) Bagi guru dapat memperkenalkan siswa model pembelajaran yang baru dan berbeda agar tercipta suasana belajar yang menyenangkan sehingga siswa dapat mengembangkan kemampuan berpikir mereka untuk mengatasi permasalahan atau persoalan dalam belajar. (3) bagi sekolah agar meningkatkan fasilitas yang sudah ada agar proses belajar mengajar dikelas bisa lebih baik lagi. (4) bagi peneliti selanjutnya, penulis mengharapkan skripsi ini dapat digunakan sebagai referensi untuk melanjutkan penelitian berikutnya agar lebih bermanfaat bagi dunia, dapat juga divariasikan dengan mengubah model pembelajaran ataupun materi pembelajaran yang digunakan.

\section{DAFTAR PUSTAKA}

Amijaya, S.L, Ramdani A dan Merta W. (2018). Pengaruh Pembelajaran Inkuiri Terbimbing Terhadap Hasil Belajar dan Kemampuan Berpikir Kritis Peserta Didik. Jurnal Pijar Mipa, 13(2), 94-99. 
Penerapan Model Pembelajaran...

Fatiqin, A, Amilda dan Sari H.M. (2018). Penerapan Model Pembelajaran Inkuiri Terbimbing terhadap Kemampuan Kognitif Siswa pada Materi Perubahan Lingkungan dan Daur Ulang Limbah Kelas X di SMA. Jurnal Edubiotik.3, 3(1), 53-61.

Hamiyah, N., dan Mohammad Jauhar. (2014). Strategi Belajar-Mengajar dikelas. Jakarta: Prestasi Pustaka.

Karsilah. (2017). Inovasi Model Pembelajaran Guided Inquiry untuk Meningkatkan Kemampuan Kognitif Siswa SMP". Indonesian Journal of Science and Education, 1(1), 49-56.

Nurdyansyah dan Eni Fariyanti. (2016). Inovasi Model Pembelajaran. Sidoarjo: Nizamia Learning Center.

Putri, D.H. (2009). Penerapan Model Inkuiri Terbimbing Tipe A Menggunakan Media Powerpoint pada Mata Kuliah Fisika Dasar 1 Konsep Dinamika Partikel Mahasiswa Semester 1 T.A Ganjil 2008/2009 Prodi P.Fisika FKIP UNIB. Jurnal Exacta, 7(2), 56-62.

Rusman. (2014). Model - model Pembelajaran Mengembangkan Profesionalisme Kedua. Jakarta: Rajawali Pers.

Guru Edisi

Sinuraya, J., dan Mihardi S. (2019). Meningkatkan Hasil Belajar Mahasiswa Melalui Penerapan Model Pembelajaran Inkuiri Terbimbing pada Matakuliah Fisika Umum". Jurnal Penelitian bidang pendidikan, 25(2), 16-23.

Sihombing, R. (2015). Penerapan Pendekatan Inkuiri Terbimbing (Guided Inquiry Approach) Pada Pembelajaran Fisika Terhadap Hasil Belajar Ditinjau dari Minat Belajar Peserta Didik Kelas X SMA Negeri 3 Jayapura. Jurnal IImu Pendidikan Indonesia, 3(2), 37-49.

Sukma., Komariyah L., dan Syam M. (2016). Pengaruh Model Pembelajaran Inkuiri Terbimbing (Guided Inquiry) dan Motivasi Terhadap Hasil Belajar Fisika Siswa. Santifika: Jurnal IImu Pendidikan MIPA dan MIPA, 18(1), 59-63.

Sumarni, S. (2017). Pengaruh Model Pembelajaran Inkuiri Terbimbing Terhadap Hasil Belajar Kognitif Peserta Didik di SMA Negeri 01 Manokwari (Studi Pada Pokok Bahasan Kelarutan dan Hasil Kali Kelarutan). Jurnal Nalar Pendidikan, 5(1), 21-30.

Suranti, N.M.Y., Gunawan dan Sahidu, H. (2016). Pengaruh Model Project Based Learning Berbantuan Media Virtual Terhadap Penguasaan Konsep Peserta Didik Pada Materi Alat-alat Optik. Jurnal Pendidikan Fisika dan Teknologi, 2(2), 73-79.

Trianto. (2011). Model-Model Pembelajaran Inovatif Berorientasi Konstruktivistik. Jakarta: Prestasi Pustaka.

Wahyuni,S., Kosim dan Gunawan. (2018). Pengembangan Perangkat Pembelajaran Fisika Berbasis Inkuiri Terbimbing Berbantuan Eksperimen Untuk Meningkatkan Penguasaan Konsep Siswa. Jurnal Pendidikan Fisika dan Teknologi, 4(2), 240-246.

Yulianci, S., Gunawan dan Aris D. (2017). Model Inkuiri Terbimbing Berbantuan Multimedia Interaktif Untuk Meningkatkan Penguasaan Konsep Fisika Peserta Didik. Jurnal Pendidikan Fisika dan Teknologi, 3(2), 146-154. 